\title{
REVERSE-BIAS LEAKAGE IN SCHOTTKY DIODES
}

\author{
P. Pipinys, A. Rimeika, and V. Lapeika \\ Department of Physics, Vilnius Pedagogical University, Studentu 39, LT-08106 Vilnius, Lithuania \\ E-mail: fizdidkat@vpu.lt
}

Received 29 January 2007

\begin{abstract}
Reverse-bias current-voltage $\left(I_{\mathrm{R}}-V\right)$ characteristics of Al- $n / \mathrm{GaAs}$ Schottky diodes have been studied in a temperature range from 92 to $333 \mathrm{~K}$. The results are explained on the basis of phonon-assisted tunnelling model. It is shown that the temperature dependence of the reverse current $I_{\mathrm{R}}$ could be caused by the temperature dependence of the electron tunnelling rate from traps in the metal-semiconductor interface to the conduction band of the semiconductor.

Temperature-dependent $I_{\mathrm{R}}-V$ data obtained by Zhang et al [J. Appl. Phys. 2006; 99: 023703] and Osvald et al [Microelectron. Eng. 2005; 81: 181] for Schottky diodes fabricated on $n$-GaN are reinterpreted in terms of a phonon-assisted tunnelling model. The temperature and bias voltages dependences of an apparent barrier height (activation energy) observed by other researchers are also explained in the framework of this model.
\end{abstract}

Keywords: Schottky diodes, GaAs, GaN, phonon-assisted tunnelling, barrier height

PACS: 73.30.+y, 73.43.Jn, 73.50.Fq

\section{Introduction}

In spite of great number of works in the domain, the mechanism of current in Schottky barrier diodes is not fully understood. In terms of a classical thermionic emission theory [1] the forward current density is given by

$$
j=j_{0}\left[\exp \left(\frac{q V}{n k T}\right)-1\right]
$$

where

$$
j_{0}=A^{*} T^{2} \exp \left(\frac{-q \Phi_{\mathrm{b} 0}}{k T}\right)
$$

is the saturation current density, $A^{*}$ is the effective Richardson constant, $\Phi_{\mathrm{b} 0}$ is the Schottky barrier height (SBH), $k$ is the Boltzmann constant, and $n$ is the ideality factor which describes the deviation of practical diodes from the pure thermionic emission model characterized by $n=1$.

A so-called Richardson plot of $\ln \left(j_{0} / A^{*} T^{2}\right)$ versus inverse temperature $1 / T$ is often used to determine the SBH from the slope of the thermally activated behaviour. According to Eq. (2), one obtains

$$
\Phi_{\mathrm{b} 0}=-\frac{k T}{q} \ln \left(\frac{j_{0}}{A^{*} T^{2}}\right),
$$

and the plot of $\ln \left(j_{0} / A^{*} T^{2}\right)$ versus $1 / T$ should yield a straight line with an activation energy $E_{\mathrm{act}}=-q \Phi_{\mathrm{b} 0}$ if the SBH $\Phi_{\mathrm{b} 0}$ is independent of temperature. However, in most cases these plots do not yield straight lines [25]. The curving in these plots is due to the temperature dependences of both $\Phi_{\mathrm{b} 0}$ and $n$.

In the case of reverse bias voltage, when $(q V / k T) \gg$ 1 , for the current density $j_{\mathrm{r}}$ from Eq. (2) one obtains

$$
j_{\mathrm{r}}=A^{*} T^{2} \exp \left(\frac{-q \Phi_{\mathrm{br}}}{k T}\right) \text {. }
$$

The apparent SBH $\Phi_{\text {br }}$ calculated from the gradient of the Richardson plot lines will be lower than $\Phi_{\mathrm{b} 0}$ due to the lowering of the barrier height caused by imageforce. However, in experiments the obtained decrease in barrier height with the increase in the bias voltage is larger than predicted by inclusion of the image-force lowering. This fact has been pointed out elsewhere $[3,6,7]$.

According to thermionic emission theory, the reverse bias current should saturate as the reverse bias voltage increases. However, in real Schottky diodes the expected current saturation is not observed at high reverse bias voltages. This deviation from ideal characteristics was attributed to the change of barrier height with applied voltage. Actually, a strong decrease in the apparent barrier height with the increase of bias voltage was observed for many Schottky diodes [6-12].

Analysis of the $I-V$ characteristics of Schottky diodes on the basis of thermionic emission theory re- 
veals a decrease in the apparent barrier height $\Phi_{\text {br }}$ and an increase in the ideality factor $n$ with a decrease in temperature [13-22]. Therefore, to explain the dependence of the apparent barrier height on temperature and applied bias voltage, an additional carrier transport mechanism such as tunnelling through the barrier was proposed [9, 19, 23-26].

Standard models, including thermionic emission with image force effects, interfacial layer models with and without surface states, and tunnelling do not adequately explain the temperature dependence of the quality factor and the bending of the Richardson plots. Some peculiarities of the temperature dependent $I-V$ characteristics of the Schottky diodes are often explained on the basis of a thermionic emission mechanism with Gaussian distribution of the barrier heights at the metal-semiconductor interface [3, 4, 6, 15-22, 27, 28].

The main peculiarities of reverse current-voltage characteristics measured in a wide temperature range for some Schottky diodes have been explained in $[29,30]$ by involving the phonon-assisted tunnelling processes [31] as a main carrier transport through the barrier. However, the mismatch at low bias voltages between the theory and experiment emerged, namely, at low voltages the current falls slower with bias decrease than the decrease in tunnelling rate with the field strength decreasing. For explanation of this discrepancy between the theory and experiment the Frenkel emission was taken into account in Ref. [30].

In this article we present an explanation of $I_{\mathrm{R}}-V$ data measured at different temperatures for $\mathrm{GaAs}$ diodes by the phonon-assisted tunnelling model using the equation derived by Kudžmauskas [32] which is simpler than the one used in $[29,30]$ and which well describes the experimental data in a wide range of field strengths and temperatures. On the basis of this model the data obtained by other authors for some Schottky diodes are also analysed.

\section{Experiment and comparison with theory}

The Schottky diodes were formed on the [100]oriented GaAs $n$-type wafers with free carrier concentration of $5 \cdot 10^{15} \mathrm{~cm}^{-3}$. An aluminium electrode of diameter $1.0 \mathrm{~mm}$ was evaporated at $100{ }^{\circ} \mathrm{C}$ as the Schottky contact. An ohmic contact was created on the other side of the wafer. The barrier height of these diodes determined by $C-V$ measurements was equal to $(0.60 \pm 0.02) \mathrm{eV}$. Reverse current $I_{\mathrm{R}}$ versus bias voltage $V$ characteristics were measured in the temperature

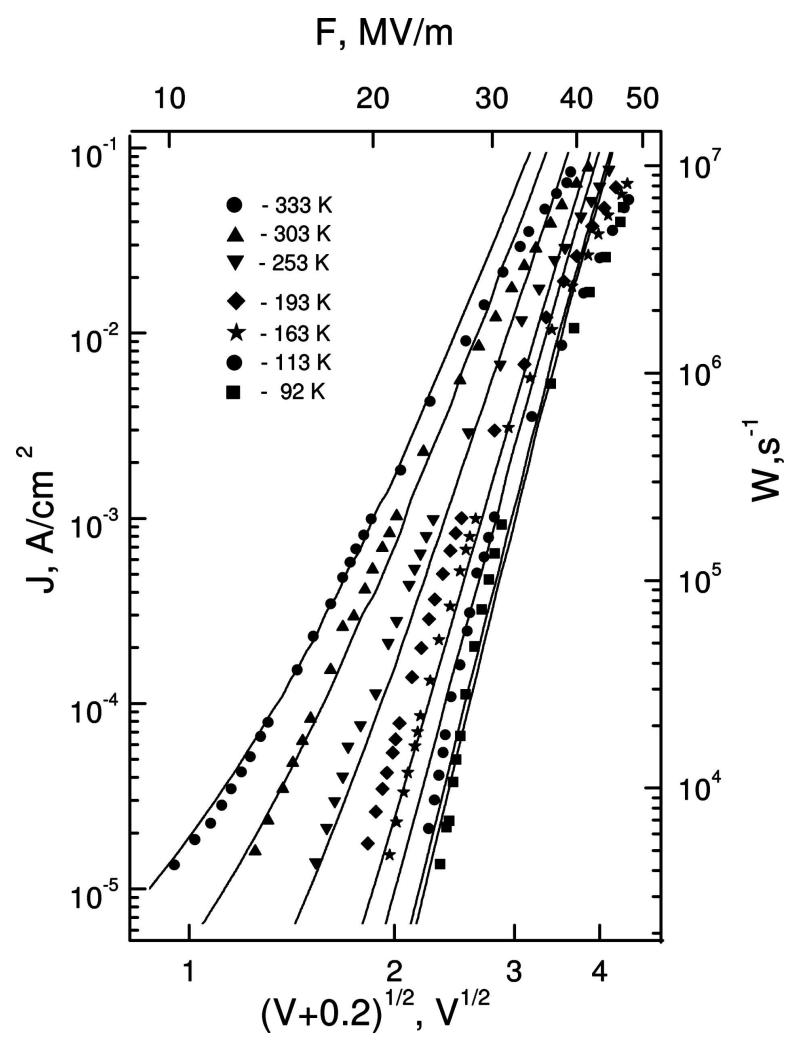

Fig. 1. Current density $J$ dependences on reverse bias voltage at different temperatures for Al- $n / \mathrm{GaAs}$ (symbols) and theoretical dependences $W(F, T)$ (solid lines) calculated using Eq. (5). The calculation have been carried out for the parameters: $E_{T}=0.60 \mathrm{eV}$, phonon energy $\hbar \omega=36 \mathrm{meV}$, electron effective mass $m^{*}=$ $0.063 m_{e}$, electron-phonon interaction constant $a=3.5$. The diffusion voltage $U_{0}=0.20 \mathrm{~V}$. The estimated $N_{S}=3.14 \cdot 10^{10} \mathrm{~cm}^{-2}$.

range of $92-333 \mathrm{~K}$. The typical $I_{\mathrm{R}}-V$ curves obtained at different temperatures for these diodes are shown in Fig. 1, where one can see the strong temperature dependence of $I_{\mathrm{R}}-V$ characteristics at low reverse bias and weaker dependence on temperature at higher bias voltages.

We explain the reverse current characteristics and their variation with temperature by a model based on phonon-assisted tunnelling developed in [29]. In accordance with this model, the current transport through the barrier is governed by a process of phonon-assisted electron tunnelling from the states near the metalsemiconductor interface to the conduction band of the semiconductor. The electron population in the states is assumed to be independent of bias voltage due to the continuous filling of interface states from the $\mathrm{Al}$ electrode.

Under these conditions, the reverse current density will be equal to $j_{\mathrm{r}}=q N_{S} W$, where $q$ is the electronic charge unit, $N_{S}$ is the electron density in the interface states, and $W$ is the electron tunnelling rate from these states, which is a function of field strength $F$ and tem- 
perature $T$. Thus, $j_{r} \propto W(F, T)$ and we can fit the current dependences obtained by measurements with the theoretical tunnel transition through the barrier rate dependences on temperature.

The transition rate $W(F, T)$ was computed using a less complicated equation than in $[29,30]$, namely, the equation (10) from Ref. [32]:

$$
\begin{aligned}
W= & \frac{q F}{\left(8 m^{*} E_{T}\right)^{1 / 2}}\left[\left(1+\gamma^{2}\right)^{1 / 2}-\gamma\right]^{1 / 2}\left[1+\gamma^{2}\right]^{-1 / 4} \\
& \times \exp \left\{-\frac{4}{3} \frac{\left(2 m^{*}\right)^{1 / 2}}{q F \hbar} E_{T}^{3 / 2}\left[\left(1+\gamma^{2}\right)^{1 / 2}-\gamma\right]^{2}\right. \\
& \left.\times\left[\left(1+\gamma^{2}\right)^{1 / 2}-\frac{\gamma}{2}\right]^{2}\right\}
\end{aligned}
$$

where

$$
\gamma=\frac{\left(2 m^{*}\right)^{1 / 2} \Gamma^{2}}{8 q \hbar F E_{T}^{1 / 2}} .
$$

Here $\Gamma^{2}=8 a(\hbar \omega)^{2}(2 n+1)$ is the width of the impurity centre absorption band caused mainly by interaction with optical phonons, where $n=[\exp (\hbar \omega / k T)-$ $1]^{-1}, \hbar \omega$ is an optical phonon energy, $E_{T}$ is the energetic depth of the centre, and $a$ is the electron-phonon interaction constant $\left(a=\Gamma_{0}^{2} /\left[8(\hbar \omega)^{2}\right]\right)$.

The calculation was performed for the electron effective mass $m^{*}=0.063 m_{e}$ [33] and the LO phonon energy of GaAs equal to $36 \mathrm{meV}$ [34] was taken. The constant $a$ was chosen from the best fit of experimental data with theoretical curves of $W(F)$ computed for different temperatures. From Fig. 1 we can see that theoretical $W(F)$ dependences describe quite well the experimental data. However, in high voltage region the increase of current with the rise in voltage is significantly slower as compared to the corresponding increase of the phonon-assisted carrier generation rate with field strength. The observed limitation of the current growth can be caused by the resistance of the ohmic electrode. The density of charge in local states estimated from the fit of experimental data to the theory was found to be equal to $N_{S}=3.14 \cdot 10^{10} \mathrm{~cm}^{-2}$.

In Fig. 2 the fit of $I_{\mathrm{R}}-V$ data measured by Ebeoǵlu et al [13] for $\mathrm{Ag} / n$-GaAs Schottky diodes with calculated $W(F)$ dependences is shown. It can be seen that theoretical curves for all measured temperatures provide a good description of the experimental dependences. We want to note that the Richardson plot of $\ln \left(I / T^{2}\right)$ versus $1 / T$ for this diode is clearly nonlinear (see inset in Fig. 2). The nonlinearity of the Richardson plots implies the dependence of barrier height on

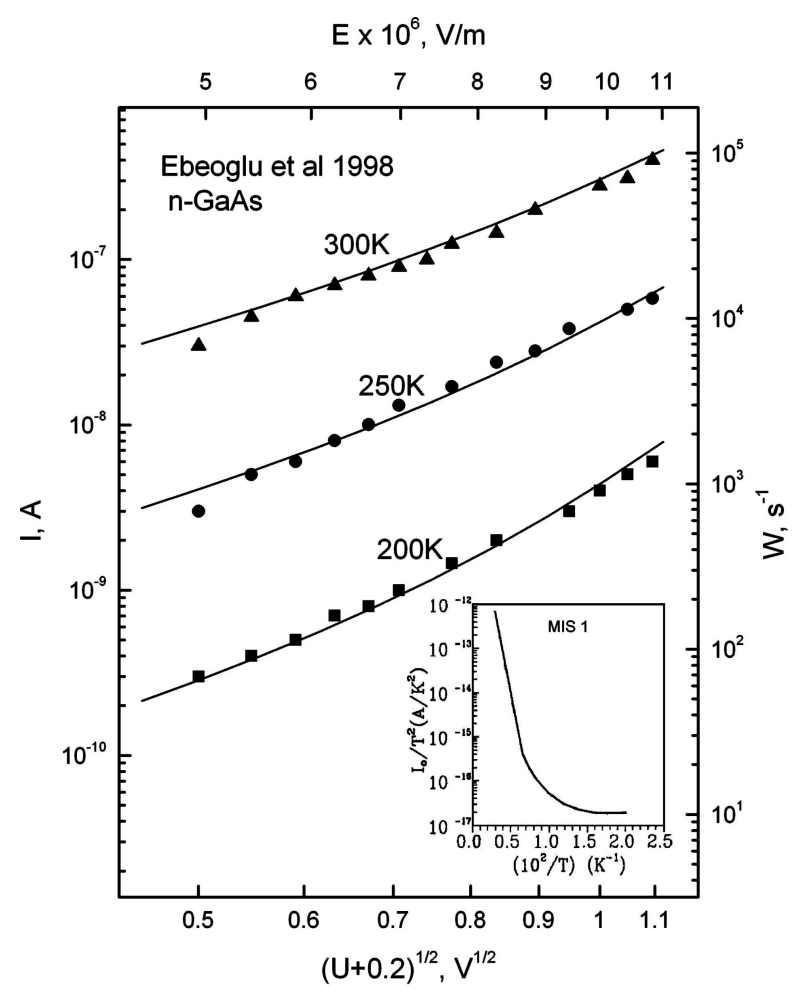

Fig. 2. Current $I$ versus reverse bias voltage dependences for the $n$-GaAs extracted from [13, Fig. 2] (symbols) fitted with the theoretical $W$ versus $F$ dependences (solid lines), computed using parameters: $E_{T}=0.60 \mathrm{eV}, \hbar \omega=36 \mathrm{meV}, m^{*}=0.063 m_{e}, a=3.5$, $N_{S}=2 \cdot 10^{10} \mathrm{~cm}^{-2}$. The inset represents dependences of $I_{0} / T^{2}$ versus $1 / T$ for the diode MIS 1 taken from the same work.

temperature which changes from $0.66 \mathrm{eV}$ at $300 \mathrm{~K}$ to $0.18 \mathrm{eV}$ at $50 \mathrm{~K}$ (see Fig. 4 in [13]). Such a change in the SBH is explained by the authors of [13] within the framework of inhomogeneous SBH, namely at low temperature the charge transport will be dominated by the current flow through the patches at lower SBH. As the temperature increases, more electrons have sufficient energy to surmount the higher barrier. As a result, according to the authors of [13], the dominant barrier height will increase with the increase of the temperature and bias voltage. However, the apparent SBH as determined from $I-V / T$ measurements, in general diminishes with the increase of bias [6-12].

The implementation of this model is promising for the explanation of temperature dependent $I-V$ characteristics in Schottky diodes fabricated on other semiconductors. Obvious examples of the research are the results obtained for diodes based on $n$-GaN. Recently, a number of papers on current mechanisms in $\mathrm{GaN}$ Schottky diodes have been published $[19,25,26,35-$ 39].

In a very recent publication Zhang et al [26] have presented temperature dependent characteristics $I_{\mathrm{R}}-V$ 


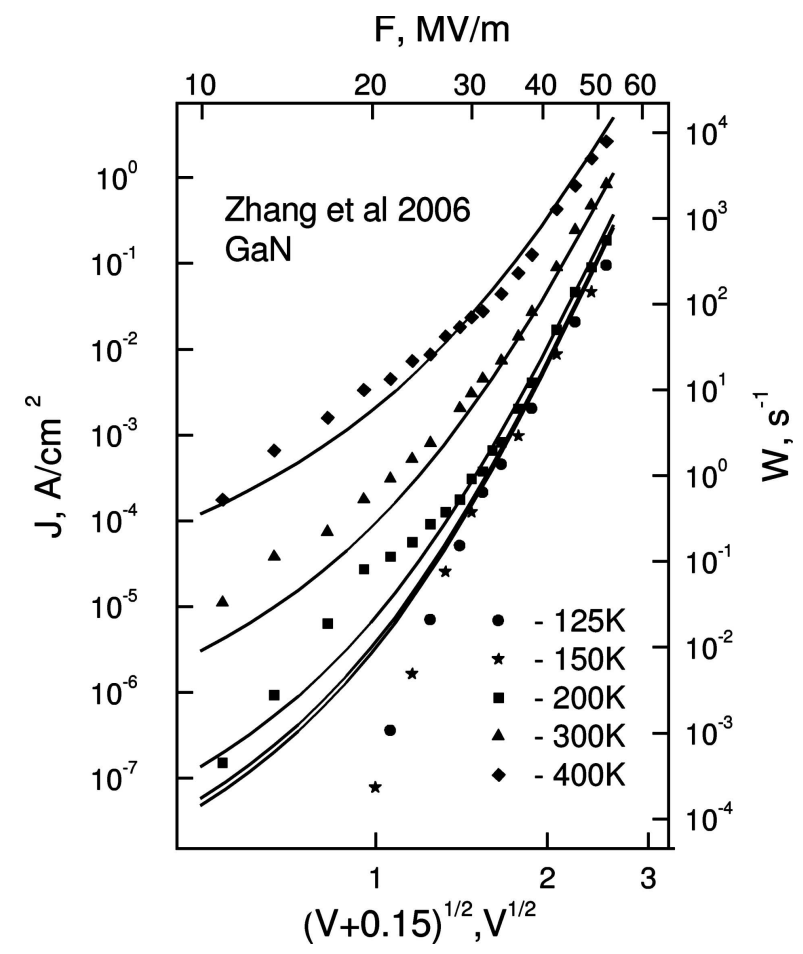

Fig. 3. Comparison of current density $J$ versus reverse bias voltage for the $n$-GaN taken from [26] (symbols) with theoretical $W$ versus $F$ dependences computed by using Eq. (5) for the parameters: $E_{T}=0.84 \mathrm{eV}, \hbar \omega=70 \mathrm{meV}, m^{*}=0.222 m_{e}, a=1.9, N_{S}=$ $2 \cdot 10^{15} \mathrm{~cm}^{-2}$.

reverse-bias leakage current in Schottky diodes fabricated from $\mathrm{GaN}$ and $\mathrm{Al}_{0.25} \mathrm{Ga}_{0.75} \mathrm{~N} / \mathrm{GaN}$ structures. Below $150 \mathrm{~K}$ the leakage current was found to be independent of temperature and was assigned to tunnelling transport. At higher temperatures the leakage current in both diode structures was described by the FrenkelPoole emission model. However, the comparison of the experimental data measured below $150 \mathrm{~K}$ with the Fowler-Nordheim tunnelling model was possible only for unusually small values of effective mass, namely of $(3.4 \pm 0.3) \cdot 10^{-3} m_{e}$ for $\mathrm{GaN}$, while the effective mass measured elsewhere [39] was found to be $0.222 m_{e}$. In Fig. 3 we display the comparison of $I-V / T$ data with the phonon assisted theory. One can see that theoretical dependences computed for the effective mass of electron value of $0.222 m_{e}$ and phonon energy equal to $70 \mathrm{meV}$ fit well with the experimental data for all temperatures at the higher bias voltages. Only for $I-V$ measured at $150 \mathrm{~K}$ for low bias voltages a significant deviation of the experiment from the theory is observed, the reason for that being not clear. We note that theoretical $W(F)$ dependences at temperatures of 125 and $150 \mathrm{~K}$ lie quite close, and are consistent with the experiment.

Similar $I_{\mathrm{R}}-V$ characteristics of GaN Schottky

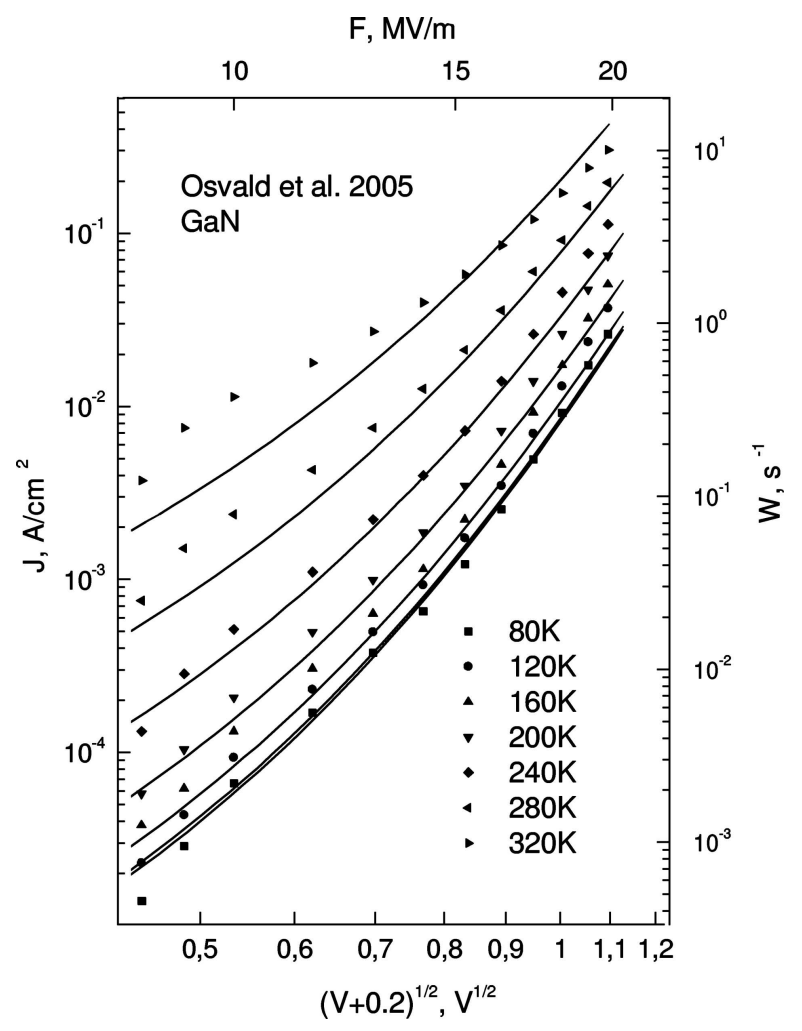

Fig. 4. Comparison of current density $J$ versus reverse bias voltage for the $n$-GaN taken from [19] (symbols) with theoretical $W$ versus $F$ dependences computed by using Eq. (5) for the parameters: $E_{T}=0.54 \mathrm{eV}, \hbar \omega=70 \mathrm{meV}, m^{*}=0.222 m_{e}, a=0.8, N_{S}=$ $2 \cdot 10^{17} \mathrm{~cm}^{-2}$.

diodes in a wide temperature range from 80 to $320 \mathrm{~K}$ have been presented by Osvald et al [19]. As can be seen from Fig. 4, the theoretical curves in all temperature range fit well with the experimental data. It is worthwhile noting that the barrier height derived from $I_{\mathrm{R}}-V$ curves has a value of $0.53 \mathrm{eV}$ at $320 \mathrm{~K}$ and decreases with decreasing the temperature, to a value of $0.16 \mathrm{eV}$ at $80 \mathrm{~K}$.

\section{Apparent barrier height dependence on temperature and bias voltages}

As mentioned above, the SBH derived from $I-V / T$ characteristics depend on temperature and bias voltage. The reason for such dependence can be explained by the fact that $\Phi_{\mathrm{B}}$ is calculated from the gradient of Richardson plots which, in general, are nonlinear (see Fig. 5 and the inset in Fig. 2). From Fig. 5 one can see that with increasing the $V$, the $\ln \left(I_{\mathrm{R}} / T^{2}\right)$ versus $1 / T$ (Richardson plot) curves become more curved and the linear region is less pronounced. With the increase of voltage the curve's slope is found to decrease and the bending of curves is observed at lower temperatures. The comparison of these data with the theoretical 


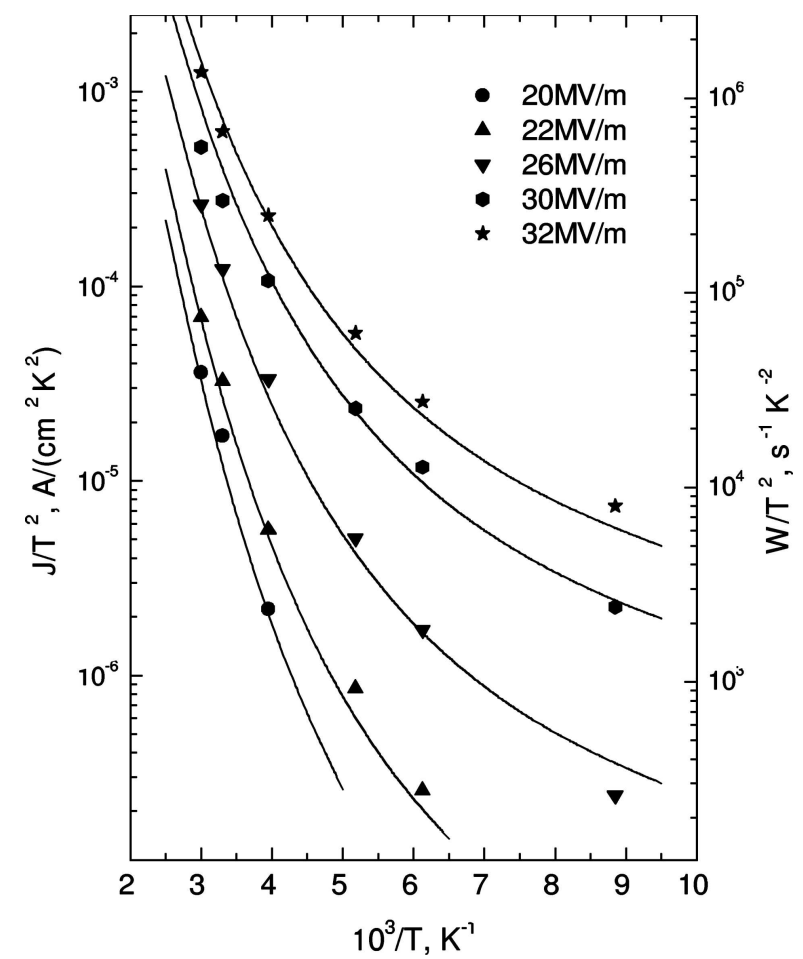

Fig. 5. The Richardson plot of $\ln \left(J / T^{2}\right)$ versus $1 / T$ dependences for the same diodes as in Fig. 1 (symbols) fitted with the theoretical $\ln \left(W / T^{2}\right)$ versus $1 / T$ dependences (solid lines) computed using the same parameters as in Fig. 1.

$W(F, T)$ versus $1 / T$ dependences shows a good fit of the theory to experiment.

Only at low field strength do these dependences become straight lines. The decrease in the slope of $\ln W(F, T)$ curves with a field strength increasing yields in our model a diminution in the apparent barrier height with applied voltage. The phonon-assisted theory predicts exactly the same value of decrease in $\Phi_{b r}$ as obtained from $I-V / T$ characteristics. The correctness of this assertion will be confirmed by comparison of the activation energy calculated from the gradient of theoretical activation energy $E_{T}$, given by

$$
E_{T}=\mathrm{d} \frac{\ln \left(W / T^{2}\right)}{(1 / T)}
$$

dependences on field strength and temperature with the experimental $\Phi_{\mathrm{br}}$ dependences on applied voltage.

Figure 6 shows the dependence of the activation energy $E_{T}$ on the field strength fitted with experimental values of $\Phi_{\mathrm{br}}$ on bias voltage extracted from $[12,17]$. As one can see, both the $E_{T}$ and $\Phi_{\text {br }}$ vary with field strength in the same way. It is worth mentioning that a fast decrease in $E_{T}$ with a field strength increase occurs in a higher field region.

In Fig. 7 the barrier height dependences on temperature from references $[19,20,22]$ fitted with $E_{T}$ de-

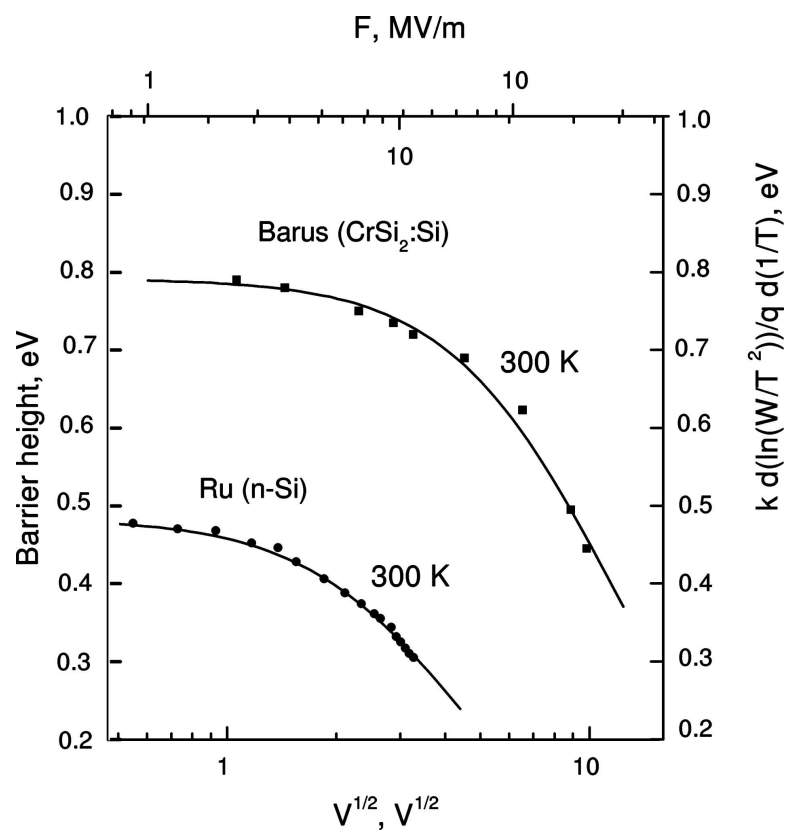

Fig. 6. Reverse bias voltage dependence of the barrier height for the diodes $\mathrm{CrSi}_{2}-n: \mathrm{Si}$ and $n$-Si from Fig. 5 and Fig. 4 in Refs. [7, 12], respectively (symbols), fitted with the gradient of the theoretical activation energy versus $F$ dependences (solid lines). Upper scale: top for the $\mathrm{CrSi}_{2}-n: \mathrm{Si}$ and bottom for the $n$-Si. Parameters for the computation: $E_{T}=0.80 \mathrm{eV}, \hbar \omega=63 \mathrm{meV}, m^{*}=0.328 m_{e}$, $a=0.8$ for $\mathrm{CrSi}_{2}-n: \mathrm{Si}$ and $E_{T}=0.50 \mathrm{eV}, \hbar \omega=63 \mathrm{meV}, m^{*}=$ $0.328 m_{e}, a=0.5$ for $n$-Si, respectively.

pendence on temperature are shown. In this case the theoretical $E_{T}$ versus $T$ dependences also reflect the experimental apparent barrier height dependences on temperature.

In conclusion, we have shown that the phononassisted tunnelling model describes well the peculiarities of reverse-bias current-voltage characteristics and their variation with temperature in Schottky diodes. In the terms of this model the voltage and temperature dependence of apparent SBH evaluated from $I-V / T$ measurements is explained (the problem of the curved behaviour of the Richardson plots falls away as well). The comparison of the temperature dependent $I-V$ characteristics with the computed tunnelling rate dependences on field and temperature, performed using basic characteristics of the material, allows us to estimate the field strength at which the free charge carriers are generated and the density of charged states near the interface between the metal and semiconductor. We suggest that including this mechanism of carrier flow through the barrier may be fruitful in resolving similar problems in the case of forward bias as well, but this demands the extension of the theory. 


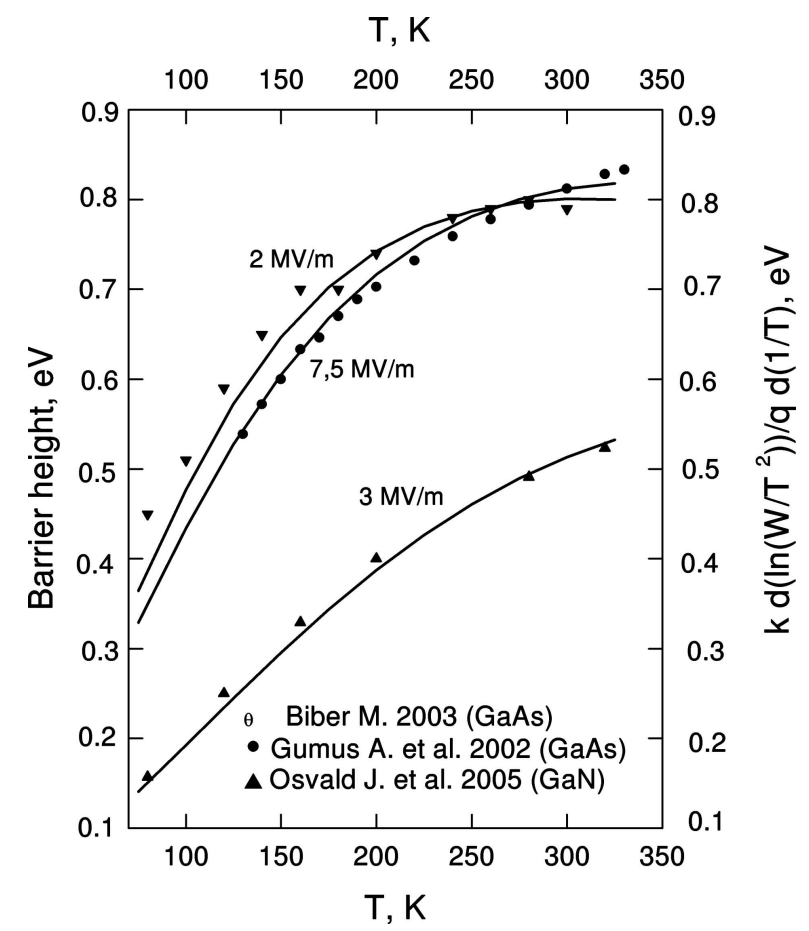

Fig. 7. Temperature dependences of the barrier height for the diodes $\mathrm{Cu}-n / \mathrm{GaAs}$ from [22], CrNiCo alloy / $n$-MBE GaAs from [20] and $\mathrm{Ni} / \mathrm{Au} / n-\mathrm{GaN}$ from [19], respectively (symbols), fitted with the theoretical activation energy versus $T$ dependences (solid lines). Parameters for the computation: $E_{T}=0.81 \mathrm{eV}$, $\hbar \omega=36 \mathrm{meV}, m^{*}=0.063 m_{e}, a=3.3(\mathrm{Cu}-n / \mathrm{GaAs}), E_{T}=$ $0.83 \mathrm{eV}, \hbar \omega=36 \mathrm{meV}, m^{*}=0.063 m_{e}, a=3$ for CrNiCo alloy $/ n$-MBE GaAs and $E_{T}=0.54 \mathrm{eV}, \hbar \omega=70 \mathrm{meV}, m^{*}=$ $0.222 m_{e}, a=0.8$ for $\mathrm{Ni} / \mathrm{Au} / n-\mathrm{GaN}$, respectively.

\section{References}

[1] S.M. Sze, Physics of Semiconductor Devices, 2nd ed. (Wiley-Interscience, New York, 1981).

[2] R. Hackam and P. Harrop, Electrical properties of nickel-low-doped $n$-type gallium arsenide Schottkybarrier diodes, IEEE Trans. Electron Devices ED-19, 1231-1238 (1972).

[3] J.H. Werner and H.H. Guttler, Barrier inhomogeneities at Schottky contacts, J. Appl. Phys. 69, 1522-1523 (1991).

[4] M.O. Aboelfotoh, Temperature dependence of the Schottky-barrier height of tungsten on $n$-type and p-type silicon, Appl. Phys. 69, 3351-3353 (1991). Solid-State Electron. 34, 51-55 (1991).

[5] P.G. McCafferty, A. Sellai, P. Dawson, and H. Elabd, Barrier characteristics of PtSi / $p$-Si Schottky diodes as determined from $I-V-T$ measurements, Solid-State Electron. 39, 583-592 (1996).

[6] A. Sing, P. Cova, and R.A. Masut, Reverse $I-V$ and $C-V$ characteristics of Schottky barrier type diodes on $\mathrm{Zn}$ doped InP epilayers by metalorganic vapor phase epitaxy, J. Appl. Phys. 76, 2336-2342 (1994).

[7] M. Barus and D. Donoval, Analysis of $I-V$ measurements on $\mathrm{CrSi}_{2}-\mathrm{Si}$ Schottky structures in a wide temperature range, Solid-State Electron. 36, 969-974 (1993).

[8] T.P. Chen, T.C. Lee, C.C. Ling, C.D. Beling, and S. Fung, Current transport and its effect on the determination of the Shottky-barrier height in a typical system: Gold on silicon, Solid-State Electron. 36, 949954 (1993).

[9] K. Maeda, I. Umezu, H. Ikoma, and T. Yoshimura, Nonideal $J-V$ characteristics and interface states of an $\alpha$-Si : H Schottky barrier, J. Appl. Phys. 68, 2858-2867 (1990).

[10] H. Ikoma and K. Maeda, Analysis of Si Schottky barrier characteristics based on a new interfacial layer model, Japan J. Appl. Phys. 30, 19-26 (1991).

[11] S. Chand and J. Kumar, Current-voltage characteristics and barrier parameters of $\mathrm{Pd}_{2} \mathrm{Si} / p$-Si(111) Schottky diodes in a wide temperature range, Semicond. Sci. Technol. 10, 1680-1688 (1995).

[12] G.P. Ru, R.L. Van Meirhaeghe, S. Forment, Y.L. Jiang, X.P. Qu, S. Zhu, and B.Z. Li, Voltage dependence of effective barrier height reduction in inhomogeneous Schottky diodes, Solid-State Electron. 49, 606-611 (2005).

[13] M.A. Ebeoǵlu, F. Temurt, and Z.Z. Öztürk, Ag/n-GaAs Schottky MIS diodes with surface insulating layers prepared using $\left(\mathrm{NH}_{4}\right)_{2} \mathrm{~S}$ solutions without water, Solid-State Electron. 42, 23-27 (1998).

[14] S. Karatas and S. Altindal, Temperature dependence of barrier heights of Au/n-type GaAs Schottky diodes, Solid-State Electron. 49, 1052-1054 (2005).

[15] M. Nathan, Z. Shoshani, G. Ashkinazi, B. Meyler, and O. Zolotarevski, On the temperature dependence of the barrier height and ideality factor in high voltage Ni-n / GaAs Schottky diodes, Solid-State Electron. 39, 1457-1462 (1996).

[16] S. Chand and J. Kumar, Evidence for the double distribution of barrier heights in $\mathrm{Pd} 2 \mathrm{Si} / n$-Si Schottky diodes from $I-V-T$ measurements, Semicond. Sci. Technol. 11, 1203-1208 (1996).

[17] S. Zhu, R.L. Van Meirhaeghe, C. Detavernier, F. Cardon, G.P. Ru, X.P. Qu, and B.Z. Li, Barrier height inhomogeneities of epitaxial $\mathrm{CoSi}_{2}$ Schottky contacts on $n$-Si(111), Solid-State Electron. 44, 625-631 (2000).

[18] H. Cetin and E. Ayyildiz, Temperature dependence of electrical parameters of the Au / $n$-InP Schottky barrier diodes, Semicond. Sci. Technol. 20, 625-631 (2005).

[19] J. Osvald, J. Kuzmik, G. Konstantinidis, P. Lobotka, and A. Georgakilas, Temperature dependence of GaN Schottky diodes $I-V$ characteristics, Microelectron. Eng. 81, 181-187 (2005).

[20] A. Gümü, A. Türüt, and N. Yalcin, Temperature dependent barrier characteristics of CrNiCo alloy Schottky contacts on $n$-type molecular-beam epitaxy GaAs, J. Appl. Phys. 91, 245-250 (2002).

[21] Y.L. Jiang, G.P. Ru, F. Lu, X.P. Qu, B.Z. Li, and $\mathrm{S}$. Yang, Ni/Si solid phase reaction studied 
by temperature-dependent current-voltage technique, J. Appl. Phys. 93, 866-870 (2003).

[22] M. Biber, Low-temperature current-voltage characteristics of MIS $\mathrm{Cu} / n-\mathrm{GaAs}$ and inhomogeneous $\mathrm{Cu} / n$-GaAs Schottky diodes, Physica B 25, 138-148 (2003).

[23] C.Y. Chang and S.M. Sze, Current transport across metal-semiconductor barriers, Solid-State Electron. 13, 727-740 (1970).

[24] Ö.S. Aniltürk and R. Turan, Electrical transport at a non-ideal $\mathrm{CrSi}_{2}-\mathrm{Si}$ junction, Solid-State Electron. 44, 41-48 (2000).

[25] E.J. Miller, E.T. Yu, Waltereit, and J.S. Speck, Analysis of reverse-bias leakage current mechanisms in GaN grown by molecular-beam epitaxy, Appl. Phys. Lett. 84, 535-541 (2004).

[26] H. Zhang, E.J. Miller, and E.T. Yu, Analysis of leakage current mechanisms in Schottky contacts to GaN and $\mathrm{Al}_{0.25} \mathrm{Ga}_{0.75} \mathrm{~N} / \mathrm{GaN}$ grown by molecular-beam epitaxy, J. Appl. Phys. 99, 023703-023709 (2006).

[27] W.P. Leroy, K. Opsomer, S. Forment, and R.L. Van Meirhaeghe, The barrier height inhomogeneity in identically prepared $\mathrm{Au} / n$-GaAs Schottky barrier diodes, Solid-State Electron. 49, 878-883 (2005).

[28] A.F. Özdemir, A. Türüt, and A. Kökce, The double Gaussian distribution of barrier heights in $\mathrm{Au} / n$-GaAs Schottky diodes from $I-V-T$ characteristics, Semicond. Sci. Technol. 21, 298-302 (2006).

[29] P. Pipinys, A. Pipinienè, and A. Rimeika, Phononassisted tunnelling in reverse biased Schottky diodes, J. Appl. Phys. 86, 6875-6878 (1999).

[30] P. Pipinys, A. Pipinienè, and A. Rimeika, Analysis of reverse current-voltage characteristics of Schottky diodes based on phonon-assisted tunnelling including
Frenkel emission mechanism, Solid-State Electron. 46, 1283-1287 (2002).

[31] F.I. Dalidchik, Multiphonon tunnel process in a homogeneous electric field, Zh. Eksp. Teor. Fiz. [Sov. Phys. JETP] 74, 472-482 (1978).

[32] A. Kiveris, Š. Kudžmauskas, and P. Pipinys, Release of electrons from traps by an electric field with phonon participation, Phys. Status Solidi A 37, 321327 (1976).

[33] K. Brennan and K. Hess, High field transport in GaAs, InP and InAs, Solid-State Electron. 27, 347-357 (1984).

[34] J.L.T. Waugh and G. Dolling, Crystals dynamics of gallium arsenide, Phys. Rev. 132, 2410-2412 (1963).

[35] K.M. Tracy, P.J. Hartlieb, S. Einfeldt, R.F. Davis, E.H. Hurt, and R.J. Nemanich, Electrical and chemical characterization of the Schottky barrier formed between clean $n$-GaN(001) surfaces and $\mathrm{Pt}, \mathrm{Au}$, and $\mathrm{Ag}$, J. Appl. Phys. 94, 3939-3948 (2003).

[36] X.M. Shen, D.G. Zhao, Z.S. Liu, Z.F. Hu, H. Yang, and J.W. Liang, Space-charge-limited currents in GaN Schottky diodes, Solid-State Electron. 49, 847-852 (2005).

[37] H.P. Hall, M.A. Awaah, and K. Das, Deep-level dominated rectifying contacts for $n$-type GaN films, Phys. Status Solidi A 201, 522-528 (2004).

[38] K.P. Hsueh, Y.M. Hsin, and J.K. Sheu, Low Schottky barrier to etched $p$-GaN using regrown AlInGaN and InGaN contact layer, J. Appl. Phys. 99, 026106026113 (2006).

[39] A.M. Witowski, K. Pakula, J.M. Baranowski, M.L. Sadowski, and P. Wyder, Electron effective mass in hexagonal GaN, Appl. Phys. Lett. 75, 4154-4155 (1999).

\title{
ATGALINĖ SROVE் ŠOTKIO DIODUOSE
}

\author{
P. Pipinys, A. Rimeika, V. Lapeika \\ Vilniaus pedagoginis universitetas, Vilnius, Lietuva
}

\section{Santrauka}

Tirta krūvio pernaša Al-n/GaAs Šotkio (Schottky) dioduose. Išmatuotos srovès tankio priklausomybès 92-333 K temperatūros srityje, esant skirtingoms pridètos atgalinès įtampos vertèms. Kai tos vertės mažos, eksperimentiškai parodyta, kad tiriamuose Šotkio dioduose atgalinès srovès tankio temperatūrinès priklausomybès yra termoaktyvacinio pobūdžio. Tokios eigos atgalinès srovès voltamperiniu charakteristikų temperatūrinès priklausomybès aiškinamos fononais paskatintų elektronų tunelinių šuolių iš sandūroje esančių lygmenų i puslaidininkio laidumo juostą modeliu.
Eksperimentiniai rezultatai palyginti su teorinemis elektronų tunelinių šuolių spartos priklausomybėmis nuo elektrinio lauko stiprio ir temperatūros. Iš palyginimų gautas lokalizuotų elektronų tankis sandūros lygmenyse $\left(\approx 10^{11} \mathrm{~cm}^{-2}\right)$ ir ịvertinti elektrinių laukų sandūroje stipriai.

Tuo pačiu modeliu aiškinamos kitų autorių išmatuotos atgalinių srovių voltamperinių charakteristikų temperatūrinès priklausomybès Ag / $n$-GaAs bei $n$-GaN Šotkio dioduose $[13,19,26]$. Taip pat aiškinamas [7, 12, 19, 20,22] darbuose nustatytas barjero aukščio (aktyvacijos energijos) kitimas nuo pridetos atgalinès itampos ir temperatūros skirtingų medžiagų Šotkio dioduose. 